\title{
The Use of Music Technologies in Field Education Courses and Daily Lives of Music Education Department Students (Sample of Atatürk University)*
}

\author{
Gökalp Parasiz \\ Department of Fine Arts Education, Necatibey Education Faculty, Balıkesir University, Balıkesir, Turkey
}

Copyright $\odot 2018$ by authors, all rights reserved. Authors agree that this article remains permanently open access under the terms of the Creative Commons Attribution License 4.0 International License

\begin{abstract}
Technology-oriented tools/devices have long been an indispensable part of music as well as music education for many years. It is of great importance in music education for students and teachers and the future of music to follow closely and use the technological developments in the present age in which technology directs the future. The aim of this research is to determine the use of technology and music technologies in music training students' field education courses in general and to determine the contribution of technology in both learning and application fields both individually and in general terms. The survey model was used in the study. Data were obtained through questionnaires. Three open-ended questions were asked to first-, second-, third- and fourth-year undergraduate students about using technology in their field courses during their fall semester and in their daily lives. The obtained data were analyzed using descriptive analysis technique, frequency-percentage and arithmetic mean. As a result, it has been found that technological materials are not used adequately in the process of the theoretical and applied courses in undergraduate education even though students benefit from music technologies in their individual work and daily life, and software Technologies are used much more than hardware Technologies.
\end{abstract}

Keywords Music Education, Technology, Music Technologies

\section{Introduction}

Technology provides rich possibilities and applications to teachers and students in educational settings and it facilitates effective and permanent learning by supporting teaching. It also offers different perspectives on events and situations.

Technology and education are branches of science in their own right and they have different theories and techniques but they are used together to improve quality in learning and teaching environments. This use reveals a new discipline, namely education technology [10]. Today, both information content and technological developments are rapidly changing and spreading. These formations naturally affect learning-teaching styles [16]. The development of technology affects both the structure of the education system and the learning-teaching activities. In order to make progress in education, the use of technology in educational activities is very important [2].

In the Works; motivation, is highlighted as the necessity of information age, new teaching techniques, and the necessity of using technology in education $[9,15]$. Dissemination and implementation of educational innovations are largely dependent on the adoption of these innovations by teachers. For this reason, Information Communication Technology not only helps students to get information faster and easier during their education process, but also provides richer learning environments [17].

According to İşman [10] the reasons for the use of technology in education are specified as;

- Providing rapid spread of information

- Design of the individual learning environment

- Design of the active learning environment

- Learning to think critically

- Cooperative working opportunity

- Increasing interpersonal communication

- Global training opportunity

- Increased motivation to learn information.

It can be said that the information technology course has an important role in the curriculum for an effective use of technology in primary schools. However, in recent years, it has been considered as important to incorporate the tools of information technology into the education process in all 
courses, instead of teaching information technology as a lesson [13].

Technology-centric tools have long been an indispensable part of music and music education. In music education, students and teachers should be able to follow and use these technological developments closely as in this age, technology leads the future, it is also important for the future of education. "As education technologies play an important role both in learning and teaching, no doubt, music teachers need to have the knowledge and skills to use these technologies" [7]. Music teacher education draws attention to because it is not only based on a scientific / artistic basis among the disciplines by its institution, rule and function, but also it is open to the possibility of utilizing all kinds of technological equipment required by this age [11].

The technology that has been shown in the field of music education has given a new perspective to the understanding of education. The tools in music education combined with technology, bring a very practical form of technology in the music curriculum, provide an expanded education for music students and help them to step into the 21 st century music world [8]. In music education, thanks to technology applications, it has been noticed that the music course has become more interesting among the students. It has also been observed in studies that it helps to get self-confidence, provides a more productive and effective learner, strengthens group work, influences critical thinking and problem solving positively, grasps music science and artistic dimension [4]. Instructional materials, especially computer technology, provide important contributions to the realization of effective learning by laying the groundwork for this. It can be argued that a teaching material gives the best possible use of the educational potential of the intended target audience [16]. The use of music production tools together with the students is a great way to give them composing, sound phonics and critical listening abilities. Learning and self-confidence with advanced applications take time. But there is nothing that can take place in learning and experience instead of using these tools [13]. For example, the use of software programs in music lessons helps newcomers to improve their composing and creativity skills by providing new methods and provides them important contributions in individual and group activities (Robyler and Edwards, 2000). By using music technology, you can preserve the performance of a stage for thousands of listeners. You can listen to thousands of musical expressions when you want. A recording can be listened to thousands of times for a review unlike a live concert [5].

The use of technologies can receive the content of the lessons in music lessons, increase the motivation of the students by increasing their interest and participation in the lessons so this will bring effective / lasting learning and affect the achievement levels positively.
The aim of this research is to determine the general use of technology and music technologies in the field education courses of music education students and to determine the contribution of technology in the fields of learning and application both individually and in general terms. From this point of view, the question of how music education students are using music technology in field education courses and everyday life constitutes the problem cue of the research. Depending on the problem sentence, the sub-problems are handled as;

1. How do music education students benefit from music technology in their studies and individual studies of field education courses?

2. How do music education students benefit from software-based music technology in their daily lives?

3. How do music education students benefit from hardware music technology in their daily lives?

\section{Method}

It is a descriptive research that is appropriate to the General Screening Model. "General screening models are a set of screenings on a group or a sample that will come from all parts of the universe in order to arrive at a general judgment about the universe in a phase consisting of a large number of elements. In such an approach, the interested event, matter, individual, group, institution, subject, variables of unit and state are tried to be described separately. This description may be limited to past or present time, or may be developmental as a function of time" [11].

Descriptive researches are also known as surveys. Surveys and interview techniques have a great role in survey research. From this point of view, a questionnaire was developed on how and in what extent students use music technology in the research on the basis of expert opinions. Scope validity of the questionnaire was obtained by expert opinions. The developed questionnaire consists of 3 questions with multiple answers. Firstly the data about the 20 in-class activities and the music technologies used in the extra-curricular activities, and also the data about the situations in which students use software-based music technologies in their daily lives were collected. Finally, the data was gathered by means of multiple answers on the situation of using the hardware music technologies in daily life of the students. The collected data was transferred to SPSS 17.0 software and the distributions (f, \%) of the multiple answers related to each question were determined and it was tried to show that which music technologies were used by students, where and how.

The study group is composed of 75 students who are educated at Atatürk University Kazim Karabekir Education, Faculty Fine Arts Education Department, Music Education Department in 2017-2018 academic year. 


\section{Results}

\subsection{How Are Music Education Students Benefiting from Music Technologies in the course of Their Field Education Courses and in Their Individual Lessons? The Findings for the Question Have Been Interpreted Separately for Each Course.}

In Table 1, it was determined that all 24 students who took the Turkish Music Polyphonic Lecture used technologies such as "Finale, Smart Board and $5+1$ Sound System" in the course of the lesson. It was determined that in individual studies about the course, 24 learners (100 percent) used "Finale"; in the non-school working environment, 10 students (41.6 percent) used "Electronic org"; In the tempo control, 7 students (29.1 percent) used "Metronome" ; in the sample work listening 22 students (91.6 percent) used "You Tube"; for polyphonic applications 6 students (25 percent) used "Garage Band"; and for chorus arrangements 2 students ( 8.3 percent) used "Acapella" as music technologies.

In Table 2, it is seen that all 75 students who have taken the Music Hearing Reading and Writing courses use Technologies such as "Electronic Organ, Finale, Smart Board and $5+1$ Sound System" in the courses. In the study of listening to $\mathrm{mp} 3$ recordings and accompaniments of the solfege books 35 students (46.6 percent) used "You Tube"; in the non-school working environments technology, 30 students (40 percent) used "electronic organ"; in the study by listening to TFM and TCM 28 students ( 37.3 percent) used "Google Play Music" as music technologies in the individual studies about the course.

In Table 3, it is seen that all of the 75 students who took the Individual Instrument course use technologies such as "Electronic Org, Finale, Smart Board and $5+1$ Sound System". In the individual studies about the course; It has been identified that in the process of listening to $\mathrm{mp} 3$ recordings and accompaniments of solfege books, 70 students (93.3 percent) used "You Tube", When tuning the instrument and controlling the intonation, 30 learners(40 percent) used "n-Track" 20 students( 26.6 percent) had "tuning device",14 students(18.6 percent) used "Tuner Lite by Plusadd" , 7 students (9.3 percent) used "Soundcorset" programs; for tempo controlling 12 students (16 percent) used "pro metronome"; 6 students (8 percent) used "Spotify" program to listen to the records of the studies and works and 3 students (4 percent) used "smart phone" for registration program to listen to themselves and to check the errors of the studies and works.

Table 1. Turkish Music Polyphony

\begin{tabular}{|c|c|c|c|c|c|}
\hline Course name & $\begin{array}{l}\text { Music Technologies Used in the } \\
\text { Course }\end{array}$ & $\begin{array}{l}\text { Music Technologies Used in } \\
\text { Individual Work Related to the } \\
\text { Course }\end{array}$ & Number of Students & f & $\%$ \\
\hline \multirow{6}{*}{$\begin{array}{l}\text { Turkish Music } \\
\text { Polyphony }\end{array}$} & \multirow{6}{*}{$\begin{array}{l}\text { Finale } \\
\text { Smart Board } \\
5+1 \text { Sound System }\end{array}$} & Finale & 24 & 24 & 100 \\
\hline & & Electronic Organ & 24 & 10 & 41.6 \\
\hline & & Metronome & 24 & 7 & 29.1 \\
\hline & & You Tube & 24 & 22 & 91.6 \\
\hline & & Garage Band & 24 & 6 & 25 \\
\hline & & Acapella & 24 & 2 & 8.3 \\
\hline
\end{tabular}

Table 2. Musical Hearing Reading and Writing

\begin{tabular}{|c|c|c|c|c|c|}
\hline Course name & $\begin{array}{l}\text { Music Technologies Used } \\
\text { in the Course }\end{array}$ & $\begin{array}{l}\text { Music Technologies Used in Individual } \\
\text { Work Related to the Course }\end{array}$ & $\begin{array}{l}\text { Number of } \\
\text { Students }\end{array}$ & f & $\%$ \\
\hline \multirow{3}{*}{$\begin{array}{l}\text { Musical Hearing } \\
\text { Reading and } \\
\text { Writing }\end{array}$} & \multirow{3}{*}{$\begin{array}{l}\text { Electronic Organ } \\
\text { Finale } \\
\text { Smart Board } \\
5+1 \text { Sound System }\end{array}$} & You Tube & 75 & 35 & $\overline{46.6}$ \\
\hline & & Electronic organ & 75 & 30 & 40 \\
\hline & & Google Play Music & 75 & 28 & 37.3 \\
\hline
\end{tabular}

Table 3. Individual Instrument

\begin{tabular}{|c|c|c|c|c|c|}
\hline Course name & $\begin{array}{l}\text { Music Technologies Used in the } \\
\text { Course }\end{array}$ & $\begin{array}{l}\text { Music Technologies Used in Individual } \\
\text { Work Related to the Course }\end{array}$ & $\begin{array}{l}\text { Number of } \\
\text { Students }\end{array}$ & f & $\%$ \\
\hline \multirow{8}{*}{$\begin{array}{l}\text { Individual } \\
\text { Instrument }\end{array}$} & \multirow{8}{*}{$\begin{array}{l}\text { Metronome } \\
\text { Bluetooth Speaker }\end{array}$} & You Tube & 75 & 70 & 93.3 \\
\hline & & n-Track & 75 & 30 & 40 \\
\hline & & Tuning Device & 75 & 20 & 26.6 \\
\hline & & Tuner Lite by Plusadd & 75 & 14 & 18.6 \\
\hline & & Pro metronome & 75 & 12 & 16 \\
\hline & & Soundcorset & 75 & 7 & 9.3 \\
\hline & & $\overline{\text { Spotify }}$ & 75 & 6 & 8 \\
\hline & & Recorder & 75 & 3 & 4 \\
\hline
\end{tabular}


Table 4. Individual Voice Training

\begin{tabular}{|c|c|c|c|c|c|}
\hline Course name & $\begin{array}{l}\text { Music Technologies Used in } \\
\text { the Course }\end{array}$ & $\begin{array}{l}\text { Music Technologies Used in Individual } \\
\text { Work Related to the Course }\end{array}$ & $\begin{array}{l}\text { Number of } \\
\text { Students }\end{array}$ & f & $\%$ \\
\hline \multirow{7}{*}{$\begin{array}{l}\text { Individual Voice } \\
\text { Training }\end{array}$} & \multirow{7}{*}{ Not Used } & You Tube & 75 & 35 & 46.6 \\
\hline & & Electronic organ & 75 & 10 & 13.3 \\
\hline & & Spotify & 75 & 4 & 5.3 \\
\hline & & Apple Music & 75 & 2 & 2.6 \\
\hline & & Google Play Music & 75 & 1 & 1.3 \\
\hline & & Tuning Device & 75 & 1 & 1.3 \\
\hline & & Recorder & 75 & 1 & 1.3 \\
\hline
\end{tabular}

Table 5. School Instruments

\begin{tabular}{|c|c|c|c|c|c|}
\hline Course name & $\begin{array}{l}\text { Music Technologies Used in } \\
\text { the Course }\end{array}$ & $\begin{array}{l}\text { Music Technologies Used in Individual } \\
\text { Work Related to the Course }\end{array}$ & $\begin{array}{l}\text { Number of } \\
\text { Students }\end{array}$ & f & $\%$ \\
\hline \multirow{3}{*}{$\begin{array}{l}\text { School } \\
\text { Instruments }\end{array}$} & \multirow{3}{*}{ Not Used } & n-Track & 75 & 24 & 32 \\
\hline & & Tuning Device & 75 & 22 & 29.3 \\
\hline & & Tuner Lite by Plusadd & 75 & 18 & 24 \\
\hline
\end{tabular}

Table 6. Music Culture

\begin{tabular}{|c|c|c|c|c|c|}
\hline Course name & $\begin{array}{l}\text { Music Technologies Used in } \\
\text { the Course }\end{array}$ & $\begin{array}{l}\text { Music Technologies Used in Individual } \\
\text { Work Related to the Course }\end{array}$ & $\begin{array}{l}\text { Number of } \\
\text { Students }\end{array}$ & f & $\%$ \\
\hline Music Culture & Not Used & You Tube & 75 & 25 & 33.3 \\
\hline
\end{tabular}

Table 7. Piano

\begin{tabular}{|lllrrr|}
\hline Course name & $\begin{array}{l}\text { Music Technologies Used in } \\
\text { the Course }\end{array}$ & $\begin{array}{l}\text { Music Technologies Used in Individual } \\
\text { Work Related to the Course }\end{array}$ & $\begin{array}{l}\text { Number of } \\
\text { Students }\end{array}$ & f & \% \\
\hline \multirow{4}{*}{ Piano } & & You Tube & 75 & 68 & 90.6 \\
\cline { 3 - 6 } & Metronome & Metronome & 75 & 20 & 26.6 \\
\cline { 3 - 6 } & & Pro metronome & 75 & 15 & 20 \\
\cline { 2 - 6 } & & Soundcorset & 75 & 13 & 17.3 \\
\cline { 2 - 6 } & & Metronome-Gismart & 75 & 10 & 13.3 \\
\hline
\end{tabular}

In Table 4, all 75 students who attended the Individual Voice Training course stated that they did not use music technologies in the courses. In the individual studies about the course; It was specified that 35 students (46.6 percent) used "You Tube" to listen to the records of works and etudes, 4 students (5.3 percent) used "Spotify", 2 students (2.6 percent) used "Apple Music", 1 student used "Google Play Music" in the non-school working environments technology, 1 student (13.3 percent) used "electronic organ", 1 student used " accordion " for the intonation and 1 student ( 1.3 percent) used "self-recording device" to listen to themselves as music technologies.

In Table 5, all 75 students who took the School Instruments class indicated that they did not use music technologies in the courses. In the individual studies about the course; it was determined that 24 students ( 32 percent) used "n-track", 22 students (29.3 percent) used "tuner device" and 18 students (24 percent) used "Tuner Lite by
Plusadd" as music technologies for instrumentation and intonation control.

In Table 6, all 75 students who attended the Music Culture course stated that they did not use music technologies in the courses. In the individual studies about the course; it was determined that 25 students ( 33.3 percent) used "You Tube" to listen to samples from world music.

Table 7 states that all 75 students who take the piano lesson use "metronome" in the course of the lesson. Students specified that in the individual studies about the course; 68 students (90.6 percent) used "You Tube" in the listening of works and etudes, 20 students (26.6 percent) used "metronome" for instrumentation and intonation control, 15 students (20 percent) used "Pro metronome", 13 students (17.3 percent) used "Soundcorset", 10 students (13.3 percent) used "Metronome-Gismart" as a music program. 
Table 8. Choir

\begin{tabular}{|lllccc|}
\hline Course name & $\begin{array}{l}\text { Music Technologies Used in } \\
\text { the Course }\end{array}$ & $\begin{array}{l}\text { Music Technologies Used in Individual } \\
\text { Work Related to the Course }\end{array}$ & $\begin{array}{l}\text { Number of } \\
\text { Students }\end{array}$ & f & \% \\
\hline \multirow{3}{*}{ Choir } & & You Tube & 75 & 29 & 38.6 \\
\cline { 3 - 6 } & \multirow{3}{*}{ Not Used } & n-Track & 75 & 5 & 6.6 \\
\cline { 3 - 6 } & & Tuning Device & 75 & 3 & 4 \\
\cline { 2 - 6 } & & Tuner Lite by Plusadd & 75 & 1 & 1.3 \\
\hline
\end{tabular}

Table 9. Harmony-Counterpoint-Parity

\begin{tabular}{|c|c|c|c|c|c|}
\hline Course name & $\begin{array}{l}\text { Music Technologies Used in } \\
\text { the Course }\end{array}$ & $\begin{array}{l}\text { Music Technologies Used in Individual } \\
\text { Work Related to the Course }\end{array}$ & $\begin{array}{l}\text { Number of } \\
\text { Students }\end{array}$ & f & $\%$ \\
\hline \multirow{6}{*}{$\begin{array}{l}\text { Harmony-Counterpoint- } \\
\text { Accompaniment }\end{array}$} & \multirow{6}{*}{$\begin{array}{l}\text { Finale } \\
\text { Smart Board } \\
5+1 \text { Sound System }\end{array}$} & Finale & 50 & 30 & 60 \\
\hline & & Garagaband & 50 & 10 & 20 \\
\hline & & Acapella & 50 & 8 & 16 \\
\hline & & Sibelius & 50 & 5 & 10 \\
\hline & & Apple Music & 50 & 1 & 2 \\
\hline & & Google Play Music & 50 & 1 & 2 \\
\hline
\end{tabular}

Table 10. History of Turkish Music

\begin{tabular}{|c|c|c|c|c|c|}
\hline Course name & $\begin{array}{l}\text { Music Technologies Used in } \\
\text { the Course }\end{array}$ & $\begin{array}{l}\text { Music Technologies Used in Individual Work } \\
\text { Related to the Course }\end{array}$ & $\begin{array}{l}\text { Number of } \\
\text { Students }\end{array}$ & f & $\%$ \\
\hline $\begin{array}{l}\text { History of } \\
\text { Turkish Music }\end{array}$ & Not Used & You Tube & 50 & 50 & 100 \\
\hline
\end{tabular}

Table 11. Traditional Turkish Folk Music

\begin{tabular}{|c|c|c|c|c|c|}
\hline Course name & $\begin{array}{l}\text { Music Technologies Used } \\
\text { in the Course }\end{array}$ & $\begin{array}{l}\text { Music Technologies Used in Individual } \\
\text { Work Related to the Course }\end{array}$ & $\begin{array}{l}\text { Number of } \\
\text { Students } \\
\end{array}$ & f & $\%$ \\
\hline \multirow{7}{*}{$\begin{array}{l}\text { Traditional } \\
\text { Turkish Folk } \\
\text { Music }\end{array}$} & \multirow{7}{*}{ Tuning Device } & You Tube & 50 & 30 & 60 \\
\hline & & Google Play Music & 50 & 25 & 50 \\
\hline & & $\mathrm{n}$-Track & 50 & 18 & 36 \\
\hline & & Tuner Lite by Plusadd & 50 & 16 & 32 \\
\hline & & Apple Music & 50 & 15 & 30 \\
\hline & & Tuning Device & 50 & 12 & 24 \\
\hline & & Spotify & 50 & 12 & 24 \\
\hline
\end{tabular}

In Table 8, all 75 students who took the chorus course stated that they did not use music technology in the course. Students determined that in individual studies about the course; 29 students (38.6 percent) used "You Tube" to listen to work records. 5 students (6.6 percent) used "n-Track" for intonation control, 3 students (4 percent)) used "tuner device" and 1 student (1.3 percent) used "Tuner Lite by Plusadd" as a music program.

Table 9 states that all 50 students who took Harmony-Contrpuan-Accompaniment course use "Finale, Smart Board and 5+1 Sound System" in the course of the course. In individual studies about the course; 30 students (60 percent) used "Finale", 10 students (20 percent) used "Garage Band", 8 students (16 percent) used "Acapella", 5 students (10 percent) used "Sibelius", for sample work listening 1 student ( 2 percent) used "You Tube", for polyphonic applications; 6 students (25 percent) used "Apple Music" and 1 student (2 percent) used "Google Play Music" as a music program.
In Table 10, all 50 students who took Turkish Music History course stated that they did not use music Technologies in the course. In individual studies about the course; It has been determined that 50 students (100 percent) used "You Tube" to listen and understand the works belonging to the Turkish Music History.

In Table 11, all 50 students who took the Traditional Turkish Folk Music course stated that they used "Tuning device" in the course.. In individual studies about the course; It has been determined that for listening to work records 30 students (60 percent) used "You Tube", 25 students (50 percent) used "Google Play Music", 15 students (30 percent) used "Apple Music", 12 students (24 percent) used "Spotify", for tuning 18 students (36 percent) used "n-Track", 16 students(32 percent) used "Tuner Lite by Plusadd", 12 students ( 24 percent) used "Tuning device" as a music program.

In Table 12, all 50 students who took the Electronic organ education course stated that they used "Electronic 
Organ" in the courses. In individual studies about the course; It has been determined that in out-of-school settings, 31students (62 percent) used "Electronic Organ".

In Table 13, all 39 students who attended the Training Music Repertoire course stated that they did not use a music technology in the course work. In individual studies about the course; It has been determined that 15 students (38.46 percent) used the "electronic organ" in non-school working environments.

In Table 14, all 39 students who took the accompaniment course indicated that they did not use music technology in the course. In individual studies about the course; It has been determined that for listening to work records 30 students (76.92 percent) used "You Tube", 6 students (15.38 percent) used "Google Play Music", 2 students (5.12 percent) used "Apple Music", 1 student (2.56 percent) used "Spotify" and 18 students (46.15 percent) used "Electronic Organ" as music programs in non-school working environments.

In Table 15, all 39 students who took Traditional Turkish Art Music course stated that they used "Tuning Device" in the course. In individual studies about the course; It has been determined that for listening to work records 24 students (61.53 percent) used "You Tube", 16 students (41.02 percent) used "Google Play Music", 10 students (25.64 percent) used "Apple Music", 5 students (12.8 percent) 2 used "Spotify", for tuning 13 students (33.3 percent) used "n-Track", 12 students (30.76 percent) used "Tuner Lite by Plusadd", 8 students (20.51 percent) used "Tuning Device", to be able to work with Turkish music in a coma writing style and transfer it to digital media 2 students (5.12 percent) used "Mus2"as music programs.

Table 12. Electronic organ Training

\begin{tabular}{|llllrr|}
\hline Course name & $\begin{array}{l}\text { Music Technologies Used in } \\
\text { the Course }\end{array}$ & $\begin{array}{l}\text { Music Technologies Used in Individual Work } \\
\text { Related to the Course }\end{array}$ & $\begin{array}{l}\text { Number of } \\
\text { Students }\end{array}$ & f & \% \\
\hline $\begin{array}{l}\text { Electronic organ } \\
\text { Training }\end{array}$ & Electronic Organ & Electronic Organ & 50 & 31 & 62 \\
\hline
\end{tabular}

Table 13. Education Music Repertoire

\begin{tabular}{|llllc|}
\hline Course name & $\begin{array}{l}\text { Music Technologies Used in } \\
\text { the Course }\end{array}$ & $\begin{array}{l}\text { Music Technologies Used in Individual } \\
\text { Work Related to the Course }\end{array}$ & $\begin{array}{l}\text { Number of } \\
\text { Students }\end{array}$ & f \\
\hline $\begin{array}{l}\text { Education } \\
\begin{array}{l}\text { Music } \\
\text { Repertoire }\end{array}\end{array}$ & Not Used & Electronic Organ & 39 & 15 \\
\hline
\end{tabular}

Table 14. Accompaniment Playing

\begin{tabular}{|llllll|}
\hline Course name & $\begin{array}{l}\text { Music Technologies Used in } \\
\text { the Course }\end{array}$ & $\begin{array}{l}\text { Music Technologies Used in Individual } \\
\text { Work Related to the Course }\end{array}$ & $\begin{array}{l}\text { Number of } \\
\text { Students }\end{array}$ & f & \% \\
\hline & & You Tube & 39 & 30 & 76.92 \\
\cline { 2 - 6 } & & Electronic Organ & 39 & 18 & 46.15 \\
\cline { 2 - 6 } $\begin{array}{l}\text { Accompaniment } \\
\text { Playing }\end{array}$ & \multirow{2}{*}{ Not Used } & Google Play Music & 39 & 6 & 15.38 \\
\cline { 2 - 6 } & & Apple Music & 39 & 2 & 5.12 \\
\cline { 2 - 6 } & & Spotify & 39 & 1 & 2.56 \\
\hline
\end{tabular}

Table 15. Traditional Turkish Art Music

\begin{tabular}{|c|c|c|c|c|c|}
\hline Course name & $\begin{array}{l}\text { Music Technologies Used in } \\
\text { the Course }\end{array}$ & $\begin{array}{l}\text { Music Technologies Used in Individual } \\
\text { Work Related to the Course }\end{array}$ & $\begin{array}{l}\text { Number of } \\
\text { Students }\end{array}$ & f & $\%$ \\
\hline \multirow{8}{*}{$\begin{array}{l}\text { Traditional } \\
\text { Turkish Art } \\
\text { Music }\end{array}$} & \multirow{8}{*}{ Tuning Device } & You Tube & 39 & 24 & 61.53 \\
\hline & & Google Play Music & 39 & 16 & 41.02 \\
\hline & & n-Track & 39 & 13 & 33.3 \\
\hline & & Tuner Lite by Plusadd & 39 & 12 & 30.76 \\
\hline & & Apple Music & 39 & 10 & 25.64 \\
\hline & & Tuning Device & 39 & 8 & 20.51 \\
\hline & & Spotify & 39 & 5 & 12.82 \\
\hline & & Mus2 & 39 & 2 & 5.12 \\
\hline
\end{tabular}


Table 16. Orchestra / Room Music

\begin{tabular}{|c|c|c|c|c|c|}
\hline Course name & $\begin{array}{l}\text { Music Technologies Used } \\
\text { in the Course }\end{array}$ & $\begin{array}{l}\text { Music Technologies Used in Individual } \\
\text { Work Related to the Course }\end{array}$ & $\begin{array}{l}\text { Number of } \\
\text { Students }\end{array}$ & f & $\%$ \\
\hline \multirow{11}{*}{$\begin{array}{l}\text { Orchestra / Room } \\
\text { Music }\end{array}$} & \multirow{11}{*}{ Not Used } & You Tube & 39 & 30 & 76.92 \\
\hline & & Google Play Music & 39 & 24 & 61.53 \\
\hline & & $\mathrm{n}$-Track & 39 & 20 & 51.28 \\
\hline & & Tuning Device & 39 & 18 & 46.15 \\
\hline & & Metronome-Gismart & 39 & 14 & 35.89 \\
\hline & & Pro Metronome & 39 & 12 & 30.76 \\
\hline & & Spotify & 39 & 11 & 28.20 \\
\hline & & Apple Music & 39 & 9 & 23.07 \\
\hline & & Soundcorset & 39 & 4 & 10.25 \\
\hline & & Finale & 39 & 2 & 5.12 \\
\hline & & Sibelius & 39 & 1 & 2.56 \\
\hline
\end{tabular}

Table 17. Current and Popular Music

\begin{tabular}{|lllrrr|}
\hline Course name & $\begin{array}{l}\text { Music Technologies Used in } \\
\text { the Course }\end{array}$ & $\begin{array}{l}\text { Music Technologies Used in Individual } \\
\text { Work Related to the Course }\end{array}$ & $\begin{array}{l}\text { Number of } \\
\text { Students }\end{array}$ & f & \% \\
\hline & $\begin{array}{l}\text { You Tube } \\
\text { Spotify }\end{array}$ & You Tube & 39 & 30 & 76.92 \\
\cline { 2 - 6 } $\begin{array}{l}\text { Current and } \\
\text { Popular Music }\end{array}$ & $\begin{array}{l}\text { Apple Music } \\
\text { Google Play Music }\end{array}$ & Apple Music & 39 & 16 & 41.02 \\
\cline { 2 - 6 } & 5+ 1 Sound System & Spotify & 39 & 15 & 38.46 \\
\cline { 2 - 6 } & & Soundcloud & 39 & 12 & 30.76 \\
\hline
\end{tabular}

Table 18. Instrument Maintenance Repair Information

\begin{tabular}{|lllll|}
\hline Course name & $\begin{array}{l}\text { Music Technologies Used in } \\
\text { the Course }\end{array}$ & $\begin{array}{l}\text { Music Technologies Used in Individual } \\
\text { Work Related to the Course }\end{array}$ & $\begin{array}{l}\text { Number of } \\
\text { Students }\end{array}$ & f \\
\hline $\begin{array}{l}\text { Instrument } \\
\begin{array}{l}\text { Maintenance } \\
\text { Repair } \\
\text { Information }\end{array}\end{array}$ & Not Used & Not Used & 30 & - \\
\hline
\end{tabular}

In Table 16, all 39 students who took the Orchestra / Room Music lesson stated that they did not use music technology in the course work. In individual studies about the course; It has been determined that 30 students (76.92 percent) used "You Tube", 24 students (61.53 percent) used "Google Play Music", 9 students (23.07 percent) used "Apple Music", 11 students (28.20 percent) used "Spotify" for listening to work records, 20 students (51.28 percent) used "n-Track", 4 students (10.25 percent) used "Soundcorset", 18 students (46.1 percent) 5 used "Tuning Device" for tuning, 14 students $(35.89$ percent $)$ "Metronome-Gismart", 12 students (30.76 percent) used "Pro Metronome" for tempo control, 2 students (5.12 percent) used "Finale", 1 student $(2.56$ percent $)$ used "Sibelius" to write and listen to songs that couldn't be recorded.
In Table 17, all 39 students who took the Current and Popular Music lessons stated that they used music technologies such as "You Tube, Spotify, Apple Music, Google Play Music, $5+1$ Sound System" In individual studies about the course; It has been determined that 30 students (76.92 percent) used "You Tube", 16 students (41.02 percent) used "Google Play Music", 15 students (38.46 percent) used "Apple Music", 12 students (30.76 percent) used "Spotify" and 2 students (5.12 percent) used "Soundcloud" to follow current and popular music.

In Table 18, all 30 students who took the Instrument Maintenance and Repair Information course stated that they did not use a music technology in the course of the course. It is also seen that students do not use a music technology in their individual studies about the course. 
Table 19. Music Formats

\begin{tabular}{|c|c|c|c|c|c|}
\hline $\begin{array}{l}\text { Course } \\
\text { name }\end{array}$ & $\begin{array}{l}\text { Music Technologies Used in the } \\
\text { Course }\end{array}$ & $\begin{array}{l}\text { Music Technologies Used in Individual } \\
\text { Work Related to the Course }\end{array}$ & $\begin{array}{l}\text { Number of } \\
\text { Students }\end{array}$ & f & $\%$ \\
\hline \multirow{4}{*}{$\begin{array}{l}\text { Music } \\
\text { Formats }\end{array}$} & \multirow{4}{*}{$\begin{array}{l}\text { Finale } \\
\text { Smart Board } \\
\text { You Tube } \\
\text { Spotify } \\
\text { Apple Music } \\
\text { Google Play Music } \\
5+1 \text { Sound System }\end{array}$} & You Tube & 39 & 18 & 46.15 \\
\hline & & Google Play Music & 39 & 8 & 20.51 \\
\hline & & Apple Music & 39 & 2 & 5.12 \\
\hline & & Spotify & 39 & 1 & 2.56 \\
\hline
\end{tabular}

Table 20. Game Dance Music

\begin{tabular}{|lllccc|}
\hline Course name & $\begin{array}{l}\text { Music Technologies Used in the } \\
\text { Course }\end{array}$ & $\begin{array}{l}\text { Music Technologies Used in Individual } \\
\text { Work Related to the Course }\end{array}$ & $\begin{array}{l}\text { Number of } \\
\text { Students }\end{array}$ & f & \% \\
\hline \multirow{3}{*}{$\begin{array}{l}\text { Game Dance } \\
\text { Music }\end{array}$} & $\begin{array}{l}\text { You Tube } \\
\text { Spotify } \\
\text { Apple Music } \\
\text { Google Play Music }\end{array}$ & You Tube & 24 & 22 & 91.66 \\
\cline { 3 - 6 } & Google Play Music & 24 & 18 & 75 \\
\cline { 2 - 6 } & Apple Music & 24 & 16 & 66.66 \\
\cline { 2 - 6 } & Spotify & 24 & 12 & 50 \\
\hline
\end{tabular}

Table 19 states that all of the 39 students who took the Music Forms course used technologies such as "Finale, Smartboard, You Tube, Spotify, Apple Music, Google Play Music and $5+1$ Sound System". In individual studies about the course; for sample work listening, 18 students (46.15 percent) used "You Tube", 8 students (20.51 percent) used "Google Play Music", 2 students (5.12 percent) used "Apple Music" and 1 student (2.56 percent) used "Spotify" as music technologies.

Table 20 shows that all 24 students who took the Game Dance Music course used the same practices as "You Tube, Spotify, Apple Music, Google Play Music". In the individual studies about the course; it has been specified that 22 students (91.66 percent) used "You Tube", 18 students (75 percent) used "Google Play Music", 16 students (66.66 percent) used "Apple Music" and 12 students (50 percent) used "Spotify" to create materials for the end-of-period show.

\subsection{Table Music Education Findings on How to Use Software Technology in Daily Life of Students}

Table 21 shows the number and percentage of software musical technologies used by students; It has been determined that 34 students (45.3 percent) used "finale", 32 students (42.6 percent) used "n-tack", 28 students (37.3 percent) used "Google play music", 24 students (32 percent) used "Karaoke by simule", 21 students ( 28 percent) used "Shazam", 16 students (21.3 percent) used "Tuner Lite by Plusadd", 15 students (20 percent) used "Metronome-Gismart", 15 Students (20 percent) used "Apple Music", 14 students (18.6 percent) used "Pro metronome", 12 students (16 percent) used "Spotify", 11 students (14.6 percent) used "GarageBand", 11 students (14.6 percent) used "Cubase", 11 students (14.6 percent) used "Acapella", 10 students (13.3 percent) "Soundcorset", 4 students (5.3 percent) used "Fl Studio", 3 students (4 percent) used "Logic Pro", 3 students (4 percent) used
"Soundcloud", 3 students (4 used "Music Studio", 3 students (4 percent) used "Mus2", 3 students (4 percent) used "Guitar Pro 6", 3 students (4 percent) used "Acid Pro", 1 students (1.3 percent) used "Mixcraft", 1 student (1.3 percent) used "Vivavideo", 1 student (1.3 percent) used "Soundhound", 1 student (1.3 percent) used "Sibelius", 1 student (1.3 percent) used "Reaper", 1 student (1.3 percent) used "NetTube", 1 student (1.3 percent) used "Guitar Tuner", 1 student (1.3 percent) used "Deezer", 1 student (1.3 percent) used "Cross Dj", 1 student (1.3 percent) used "Ensemble Composer", 1 student (1.3 percent) used "Staffpad".

Table 21. Software Music Technologies

\begin{tabular}{|ccc|}
\hline Music Technologies (Software) & f & \% \\
\hline Finale & 34 & 45.3 \\
\hline n-Track & 32 & 42.6 \\
\hline Google Play Music & 28 & 37.3 \\
\hline Karaoke by Simule & 24 & 32.0 \\
\hline Shazam & 21 & 28.0 \\
\hline Tuner Lite by Plusadd & 16 & 21.3 \\
\hline Metronome-Gismart /Apple Music & $15 / 15$ & 20.0 \\
\hline Pro metronome & 14 & 18.6 \\
\hline Spotify & 12 & 16.0 \\
\hline GarageBand/Cubase/Acapella & $11 / 11 / 11$ & 14.6 \\
\hline Soundcorset & 10 & 13.3 \\
\hline Fl Studio & 4 & 5.3 \\
\hline Logic Pro/Soundcloud/Music & $3 / 3 / 3$ & \multirow{2}{*}{4.0} \\
\hline Studio/Mus2/Guitar Pro 6/ Acid Pro & $3 / 3 / 3$ & \\
\hline $\begin{array}{c}\text { Mixcraft- Vivavideo-Soundhound- } \\
\text { Sibelius-Reaper- NetTube-Guitar } \\
\text { Tuner-Deezer-Cross Dj-Ensemble } \\
\text { Composer-Staffpad }\end{array}$ & $1 / 1 / 1 / 1 / 1$ & \\
\hline
\end{tabular}

In Table 21, it shows that software programs such as "Finale, n-Track, Google Play Music, Karaoke by Simule, Shazam, Tuner Lite by Plusadd, Metronome-Gismart, Apple Music, Pro metronome, Spotify, GarageBand, Cubase, Acapella, Soundcorset " are used in the courses, in 
the extracurricular activities, and also in their daily lives.

\subsection{Table Findings about How Music Education Students Benefit from Hardware Music Technologies in Their Daily Lives}

Table 22. Hardware Music Technologies

\begin{tabular}{|ccc|}
\hline Music Technologies (Hardware) & f & $\mathbf{\%}$ \\
\hline Headphone & 61 & 81.3 \\
\hline Tuning Device & 34 & 45.3 \\
\hline Electronic Organ & 31 & 41.3 \\
\hline Metronome & 29 & 38.6 \\
\hline Microphone & 24 & 32.0 \\
\hline Recorder & 13 & 17.3 \\
\hline Bluetooth Speaker & 9 & 12.0 \\
\hline Mixer & 6 & 8.0 \\
\hline Amphitheater & 3 & 4.0 \\
\hline Effect Processor & 2 & 2.6 \\
\hline Synthesizer & 1 & 1.3 \\
\hline
\end{tabular}

Table 22 shows the number and percentage of hardware music technologies used by students; It's determined that 61 students (81.3 percent) used " headphone", 34 students (45.3 percent) used "Tuning device", 31 students (41.3 percent) used "Electronic organ", 29 students (38.6 percent) used "Metronome", 24 students (32 percent) used "Microphone", 13 students (17.3 percent) used "Recorder", 9 students (12 percent) used "Bluetooth speaker", 6 students ( 8 percent) used "Mixer", 3 students ( 4 percent) used "Amphitheater", 2 students ( 2.6 percent) used "Effect processor" and 1 student ( 1.3 percent) used "Synthesizer".

It is determined according to the answers that the most used hardware music technologies by students in their daily lives are "headphones, tuner, electronic organ, metronome, microphone, recorder and bluetooth speaker".

\section{Conclusions}

In the study, 20 field education courses of undergraduate students in the fall semester and the technologies used in their daily lives and the music technologies used in their individual studies for the classes were discussed. It has been determined that music technologies such as "Finale, Smart Board, $5+1$ sound system, Electronic Organ, Metronome, Bluetooth speaker, Tuner, You Tube, Spotify, Apple Music and Google Play Music" were used at 11 courses. In the remaining 9 lessons, a music technology was never used in the course. On the other hand, it has been found that students used both software and hardware music technologies intensively in their individual studies in all courses.

In the last sub-problem of the research, it has been determined that the hardware music technologies used by students in their daily lives, are "headphones, tuner, electronic organ, metronome, microphone, recorder and bluetooth speaker" and these devices are frequently used with software hardware.

\section{Discussion}

Education and technology are two basic elements that play an important role in bringing human life into a more active state. Both elements are the two basic means of the efforts of man to dominate the natural and social environment [2].

"Rapid developments and innovations in technology are affecting individuals. It has become a necessity for people to use technology in their daily lives. For this reason, Information and Communication Technologies (ICT), which is developing and becoming widespread, is being used as a tool for solving educational problems" [7].

With the use of technology in music education, it can be said that the fluency, clarity, permanence of the course and teacher-student communication will be ensured at the highest level.

"The use of technology in music education is not for the purpose of eliminating communication between the teacher and the student, or breaking down the classical education system, but for using the advantages offered by them as a supporting resource. Traditional music education has become more effective and multidimensional with the use of technology, and new technologies have transformed the music learning environment into a "technological learning center"[18].

In the study; 20 field education courses belonging to the fall semester were taken up. It has been determined that in the undergraduate education, the students do not use the technological materials in the theoretical and practical courses adequately, whereas the students use the technological products and music technologies in their individual studies and daily lives considerably and they also use the software technologies much more than the hardware technologies.

In many of the lessons on the tables, You Tube is considered as a music technology. Students stated their purpose of using You Tube as "listening to various world music and daily Turkish music from the past". For many lessons, it is important to note that You Tube has a unique music archive, and in this sense it serves the field of music technology. Another item on the tables is smart board. The smart board provides a traditional board experience by using the programs installed in it. In addition, students use note-writing programs such as "Finale, Sibelius" on the smart board. During the daily work that they do for individual instruments and individual voice training courses, the students record their performances using the recording device so they evaluate themselves by listening in the next stage. In the courses based on weekly performance, such as individual instrument lessons, individual voice training lessons, and piano lessons, the students work with the help of the metronome and it gives the tempo discipline to their performances. The use of Tuning Devices is often seen in courses such as orchestra / chamber music, traditional Turkish art music, traditional Turkish folk music, individual instruments, school 
instruments, etc., that students need to use an instrument. In individual instrument and individual voice training courses, students work by finding piano or orchestra accompaniments of works on the internet. Many on-line or off-line music listening programs such as Spotify, Apple Music, Google Play Music are used in especially the Current and Popular Music lessons and many others. Students who want to support their work by headphones use electronic organ in their courses in this sense. In addition to benefiting from the use of software programs for their intended use, students also benefit from the possibilities offered by the applications. Students use Finale for writing notes as a basic feature, they also use this computer program in harmony studies, hearing works, writing and listening to works that they cannot reach in their recordings, orchestral workshops and arrange studies. Students mainly use the n-track mobile application which performs the functions of a tuning device for tuning instruments; they also use it for intonation exercises, solfege exercises and for not carrying a second tuning device externally. "In the field of music, different forms of technology can be mentioned. Some of them can be exemplified as recording, composing, writing and editing of notes, sounding, electronic musical instruments. It is possible to reach a lot of musical knowledge through technology. Writing notes, playing musical instruments, hearing and voice training on the computer are the information, skills and activities that everyone can easily reach" [10].

In the processing of music lessons, the planning and enrichment of technological materials according to the content of the subject and the work will facilitate learning by increasing the interest and participation of the students. Nevertheless, it will significantly increase motivation and knowledge permanence of student.

Teacher candidates should be trained through their undergraduate training courses so that they can integrate technology in the lessons by acquiring knowledge and skills of effective use of the technology [6]. (Çevik, 2012: 139). The education and technology coordination that will be provided to the students throughout the undergraduate education will contribute to their professional lives in a positive way in the future.

\section{REFERENCES}

[1] Albuz, A. (2004). Müzik Öğretmenliği Eğitiminde Çok Boyutluluk, Gazi Üniversitesi, Gazi Eğitim Fakültesi
Dergisi, Cilt 24, Say1 2. 105-110

[2] Alkan, C. (2005). Eğitim teknolojisi, An1 Yayıncılık.

[3] Andaç, Y., Temiz, E. (2016). Müzik Dersinde Teknoloji Kullanımının 4. Ve 5. Sınıf Öğrencilerinin Müzik Dersine Karşı Tutumlarına Etkisi, Fine Arts (NWSAFA), 11 (4).

[4] Arapgirlioğlu, Hasan. (2003), "Müzik Teknolojisi ve Yeni Yüzyılda Müzik Eğitimi”, Malatya; Cumhuriyetimizin 80 . Y1lında Müzik Sempozyumu, 30 31Ekim 2003, İnönü Üniversitesi.

[5] Bartlet, B. And J. (1992). Pratical Recording Techniques, Sams Publishing, Indianapolis.

[6] Çevik, D. B. (2012). Müzik Bölümü Öğrencilerinin Teknoloji Kullanımına Yönelik Görüşleri, Journal of Education and Instructional Studies in the World, Volume 2, Article 20.

[7] Çevik, D. B. (2017). Examining music teachers' self-confidence levels in using information and communication Technologies for education based on measurable variables, Educational Research and Reviews.

[8] Ed. Watson, S. (2005). Technology Guide for Music Educator, Aristpro Publishing. Pennsylvania

[9] Fisher, M. (2000). Computer and technology awareness training in preservice teacher education, Tech Trends, 46(6), 21-26.

[10] İşman A., (2003). Öğretim Teknolojileri ve Materyal Geliştirme, Değişim Yayınları, İstanbul

[11] Karasar, N. (2007). Bilimsel Araştırma Yöntemi, Ankara: Nobel Yayın Dağıtım.

[12] Kirschner, P., \& Selinger, M. (2003). The State of Affairs of teacher Education with Respect to Information and Comminication Technolgy, Technology Pedagogy and Education, 12 (1) 5-17.

[13] Mason, K., M. and Moniz, M., J. (2005). Music Production, Technology Guide for Music Educator, Aristpro Publishing, Pennsylvania

[14] Roblyer, M. E.,\& Edwards, J. (2005). Integrating educational technology into teaching. (4th Ed.) Upper Saddler River, NJ: Prentice-Hall

[15] Robyler, MD., Edwards, J. (2000). Integrating educational technology into teaching, Upper Saddle River, NJ: Wyncote, PA: Shearspire, Inc.

[16] Seferoğlu, S. S. (2006). Öğretim Teknolojileri ve Materyal Tasarımı, Pegem A Yayıncılık.

[17] Sirkemaa, S. (2001). Information technology in developing a metalearning environment, Turku School of Economics and Busines Administration, Pori Unit P.O. Box 300, 28101, Finland

[18] Tecimer, B. (2006). “İnternet ve yaşam boyu müzik eğitimi”" $\mathrm{http} / / \mathrm{www}$.muzikegitimcileri.net

\footnotetext{
* This work was presented as a summary paper at the International Education and Technology Symposium in Sivas Cumhuriyet University.
} 